\title{
Microbiological Analysis of Poultry Feeds Along with the Demonstration of the Antibiotic Susceptibility of the Isolates and the Antibacterial Activity of the Feeds
}

\author{
Chanda Rani Roy ${ }^{1}$, Tasnia Ahmed ${ }^{1}$, Md. Aftab uddin ${ }^{1 *}$ \\ ${ }^{1}$ Department of Microbiology, Stamford University Bangladesh, 51 Siddeswari Road, Dhaka 1217, Bangladesh.
}

\begin{abstract}
Poultry farms and poultry product processing industries are increasing worldwide to fill up the expanding demand for protein of the escalating population. To get good growth and more eggs from the domestic birds in the poultry farms, nutritious food supplements are commonly known as the poultry feed provided. These feeds also serve as sources of bacterial, fungal and viral contamination which in turn can cause diseases in the birds and ultimately can infect the consumers if the poultry is not processed and cooked properly. In this study, in order to determine the pathogenic bacterial load five different poultry feed samples sold in local markets of Dhaka city were analyzed. All samples harbored total viable bacteria up to $5.0 \times 10^{6} \mathrm{cfu} / \mathrm{gm}$ and total fungal count up to $4.5 \times 10^{5} \mathrm{cfu} / \mathrm{gm}$. While Escherichia coli was absent in all samples; Klebsiella spp. and Aeromonas spp. were found to be present in only one sample $\left(1.4 \times 10^{6} \mathrm{cfu} / \mathrm{gm}\right.$ in sample 4 and $2.9 \times 10^{5} \mathrm{cfu} / \mathrm{gm}$ in sample 5 respectively). Staphylococcus aureus and Shigella spp. were found to be predominat in all the samples. Pseudomonas spp. and Vibrio spp. were present in 3 and 4 samples, respectively. Aeromonas spp., Vibrio spp., Salmonella spp. and Staphylococcus aureus showed $100 \% \mathrm{drug}$ resistance towards ER, NA, NVB, KAN antibiotics. The finding of the study emphasis on the prevention of contamination through a sound maintenance of quality during poultry feeds preparation, storage and maintenance. Diseased birds and their excreta must be destroyed during poultry farming. Usage of excess antibiotics must be regulated as suggested from the data of the current study that shows high resistance of the bacterial isolates from the food. Finally, the consumers should process and cook the poultry items properly to save themselves from further food hazards.
\end{abstract}

Key words: Poultry feed, contamination, pathogenic bacteria, resistance, health hazards.

\section{Introduction}

Poultry products are very popular among the people worldwide providing a source of high protein containing food. Any type of avian species used for consumption as protein source by providing meat and eggs is called poultry. The birds may be chicken, duck, turkey, pigeons, quail etc ${ }^{1,2}$. Poultry feeds are nutritious elements given to these domestic birds to make them grow properly and provide more meat and eggs $3,4,5$. Poultry feeds are prepared using bone meal, cassava waste, grains, cereals, soya beans and vegetables like tridax, water leaf, amaranthus spp. etc ${ }^{1,6}$. The feeds which are given to the domestic birds can be a source of microorganisms to them which includes bacteria, fungi as well as their secreted toxins. Escherichia spp., Enterobacter spp., Salmonella spp., Listeria spp., Streptococcus spp., Clostridia spp., etc have been isolated so far from poultry feeds and many of them showed multi-drug resistance ${ }^{7-19}$. The growth of molds deteriorates the quality of the feed and production of toxins make the feed toxic, carcinogenic and often teratogenic resulting in different types of diseases in the domestic birds ${ }^{20-29}$. Diseases like cholera, colibacillosis, listeriosis, staphylococcosis, amoebic dysentery, bacillary dysentery, salmonellosis, avian influenza, newcastle disease, infectious coryza are most common among those diseases which can transmit to the consumers as well ${ }^{9-}$ 11,30,31. Human diseases like Salmonella paratyphoid fever, traveller's diarrhea etc. can occur due to the consumption of poultry birds which contracted infections from poultry feeds ${ }^{5}$. The poultry feeds can be contaminated during preparation, by using contaminated raw materials, by improper handling, from poor storage conditions, due to high humidity, by exposure to environmental microorganisms and so on ${ }^{32}$. Contamination can be reduced by applying organic acids, organic salts, exposure to heat $\left(>80^{\circ} \mathrm{C}\right)$ etc.

Poultry farming is quite popular in Bangladesh because of its ease of handling as well as lower investment cost which is manageable for the middle class societies. However, the microbiological concerns for feeds are not properly addressed in Bangladesh which may impose several disease complications. Such a concern for public health drove the current study to (1) isolate and enumerate bacteria from the poultry feeds along with the further determination of the antibiotic susceptibility of the

*Corresponding author:

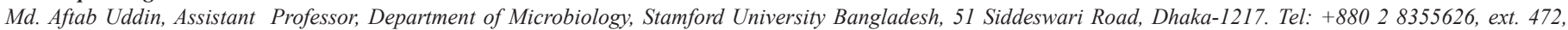
Cell: +88017581793,E-mail: afteab_mb12@yahoo.com 
bacterial isolates and (2) to detect the antibacterial activity of the feeds if present.

\section{Materials and methods}

Study area and sampling

Five types of poultry feed samples were collected from different areas of Dhaka city between the time frame of January, 2017 to April, 2017. Samples were collected in sterile glass bottles following the aseptic technique ${ }^{33}$. After collection of the samples, they were transported to the laboratory and kept at room temperature until the laboratory procedures started.

\section{Sample collection and sample preparation:}

Samples were collected early in the morning and transported and stored. Then it was subjected to microbiological analysis. ten gm of each sample was transferred to $90 \mathrm{ml}$ normal saline for homogenization and then serial dilution was done up to $10^{-5}$. For isolation of VBNC bacteria for example Vibrio spp., Salmonella spp. \& Shigella spp., $1 \mathrm{ml}$ homogenized sample was inoculated into $9 \mathrm{ml} \mathrm{APW} \mathrm{(alkaline} \mathrm{peptone} \mathrm{water)} \mathrm{and} 9 \mathrm{ml} \mathrm{SCB}$ (selenite cysteine broth) respectively for all the samples. The inoculated APW and SCB tubes were vortex mixed properly and incubated at $37^{\circ} \mathrm{C}$ for 4 to 6 hours for enrichment. After enrichment the tubes were subjected to serial dilution ${ }^{34}$.

\section{Total Viable Bacterial Count (TVBC) and Total Fungal Count (TFC)}

$0.1 \mathrm{ml}$ diluted sample from $10^{-3}$ and $10^{-5}$ dilution of the homogenized samples of poultry feed were spread onto the nutrient agar (NA) plates and sabouraud dextrose agar (SDA) plates for TVBC and total fungal load respectively. NA plates were kept in the $37^{\circ} \mathrm{C}$ incubator for 24 hours and SDA plates were kept in the $25^{\circ} \mathrm{C}$ incubator for 48 hours ${ }^{34}$.

Determination of Pseudomonas spp., Staphylococcus spp., Escherichia coli \& Klebsiella spp.

$0.1 \mathrm{ml}$ sample from $10^{-3}$ and $10^{-5}$ dilution was spread over Pseudomonas Agar, MSA (Mannitol Salt Agar), MAC (MacConkey Agar) plates and incubated overnight at $37^{\circ} \mathrm{C}$ to isolate Pseudomonas spp., Staphylococcus spp., Klebsiella spp. and Escherichia coli respectively ${ }^{34}$.

\section{Determination of $V B N C$ bacteria}

The enriched SCB and APW tubes were subjected to serial dilution up to $10^{-3}$ in normal saline. $0.1 \mathrm{ml}$ of sample from $10^{-2}$ and $10^{-3}$ dilutions were inoculated onto Thiosulfate Citrate Bile Salt Sucrose (TCBS) agar plates and Salmonella-Shigella (SS) agar plates for the detection of Vibrio spp., Aeromonas spp., Salmonella spp., and Shigella spp. ${ }^{35,36}$. All plates were incubated at $37^{\circ} \mathrm{C}$ for 24 hours ${ }^{37,38}$.

\section{Antibiotic susceptibility of the isolates found in poultry feeds}

Bacterial susceptibility to antibiotics was determined by using the standardized agar disc-diffusion method known as the Kirby Bauer method ${ }^{33}$. Antibiotics used in this study included
Gentamycin $\left(10^{1 / 4 \mathrm{~g})}\right.$, Erythromycin $\left(15^{1 / 4 \mathrm{~g})}\right.$, Ceftriaxone (301/4g), Rifampin (51/4g), Kanamycin (301/4g), Novobiocin (301/4g), Nalidixic Acid (301/4g), Amoxicillin (301/4g), Ciprofloxacin (51/4g). A suspension of the Salmonella spp., Enterobacter spp., Pseudomonas spp., Klebsiella spp., Escherichia coli, Proteus spp., Vibrio spp., Staphylococcus aureus were prepared. A sterile cotton swab was dipped into the prepared bacterial suspension and used to make lawn of the bacterial suspension evenly over the entire surface of a Mueller-Hinton agar plate. Antibiotic disc were placed aseptically over the surface of the inoculated plates using sterile forceps. The plates were then incubated at $37^{\circ} \mathrm{C}$ for 8 hours. After incubation the plates were examined \& the diameters of the zones of inhibition were measured in $\mathrm{mm}^{34}$.

Antibacterial activity of the poultry feeds against clinical isolates

The antimicrobial activity of the homogenized poultry feed samples were determined by agar well diffusion method ${ }^{40}$. Suspensions of clinical isolates (Staphylococcus spp., Pseudomonas spp., Klebsiella spp., Vibrio spp., Escherichia coli) were used to make lawn directly on the Muller-Hinton agar (MHA) media separately. Each of the five samples were then introduced (volume of 1001/4l) separately in the specified hole made in the MHA agar plates with sterile cork borer. After incubation period of 24 hours, the presence of clear zone around the sample solution indicated the presence of antibacterial activity. This indirectly indicated the presence of antibiotics in poultry feeds tested.

\section{Results and discussion}

In Bangladesh, poultry farms are very common which are responsible for commercially providing poultry feeds in the retail and super shops. Both small scale domestic poultry farms and commercial large poultry farms are available in our country. The proper growth and health status of the poultry birds depends on the quality of the supplied poultry feed. Very often low quality, locally produced feeds are provided to the birds of small farms. Such low quality feeds not only provide poor nutrition but also can harbor different types of pathogenic bacteria which can infect the birds and cause disease ${ }^{28}$. Such poultry products can cause diseases in human if not processed and cooked properly. The pathogenic bacteria from the poultry products can infect human body causing various acute and chronic diseases 39-44,35. Salmonella spp. can undergo chronic stage in human patients who might become carrier of salmonellosis towards other susceptible individual. Till now, 82 serotypes of Salmonella spp. have been reported of which 45 isolates were isolated from poultry feeds 45,46 . Enterobacteriaceae group is one of the major contaminants of poultry feed ${ }^{26}$. Poultry droppings from infected birds must be cleaned and disposed properly to reduce the transmission from droppings to other feeds, to human during handling, to fishes when they are used as fish feed ${ }^{47}$.

During the current investigation, five different types of poultry feed samples were selected for microbiological analysis. Total 
viable bacterial count was within the range of $5.0 \times 10^{4} \mathrm{cfu} / \mathrm{gm}$ to $5.0 \times 10^{6} \mathrm{cfu} / \mathrm{gm}$. Highest total fungal count $\left(4.5 \times 10^{5} \mathrm{cfu} / \mathrm{gm}\right)$ was observed in sample 04 and the lowest count $\left(2.0 \times 10^{3} \mathrm{cfu} / \mathrm{gm}\right)$ was found in sample 05. Escherichia coli was absent in all the samples. Aeromonas spp. and Klebsiella spp. were found in only one sample (sample 5 and sample 4 respectively). Staphylococcus aureus $\left(2.7 \times 10^{5} \mathrm{cfu} / \mathrm{gm}\right.$ to $\left.5.0 \times 10^{3} \mathrm{cfu} / \mathrm{gm}\right)$ and Shigella $\mathrm{spp}$. $\left(3.2 \times 10^{4} \mathrm{cfu} / \mathrm{gm}\right.$ to $\left.1.1 \times 10^{6} \mathrm{cfu} / \mathrm{gm}\right)$ were the most abundant pathogenic bacteria found to be present in all the samples. Pseudomons spp. was present in sample 01, 03 and 04. Vibrio spp. was the second most abundant pathogen in the poultry feeds. Four samples out of five harbored Vibrio spp. within the range of $1.8 \times 10^{5} \mathrm{cfu} / \mathrm{gm}$ in sample 5 to $2.4 \times 10^{5} \mathrm{cfu} / \mathrm{gm}$ in sample 4 .

In case of locally made feeds, the quality must be maintained by physical and chemical treatments to lessen the bacterial load. Storage conditions, packaging, handling should also be maintained properly. Cross contaminations must be prevented. The consumption of uncooked eggs and undercooked meat of poultry should be discouraged strongly. If not maintained properly the food products can not only be contaminated but also the contamination level will increase and finally find its way into the consumers causing illness. In a data provided by CDC it had been found that 29444 illnesses cases were confirmed among which 1184 patients were hospitalized resulting in 23 deaths only in the time period of 2009-2010. The main causative agents were Salmonella spp., Clostridium spp. and Listeria spp. ${ }^{48,49}$. Studies in different countries also showed the presence of different groups of microorganisms in poultry feed which can cause food borne infections ${ }^{50,51}$. Bacterial limit for animal feed products has been documented by EU Commission Regulation act in 2011 which stated the acceptable count of specific microbes in the feed. For example Enterobacteriaceae spp. $300 \mathrm{cfu} / \mathrm{gm}$, Salmonella spp. nil, moulds and yeast $10^{6} \mathrm{cfu} / \mathrm{ml}^{52}$.

Drug resistance has become a dreadful clinical obstacle these days. Such resistances are increasing due to mutation, gene transfer, growth with antibiotic stress, inadequate dosage of antibiotics, failure in completion of antibiotic therapy course etc $^{53}$. Drug resistant bacteria can transfer the resistance gene containing plasmid to the susceptible isolates rendering them resistant too. This makes the treatment procedures more difficult because the disease caused by the resistant microorganisms fails to resolve as the microbes are no longer sensitive towards antibiotic ${ }^{54}$. Poultry feeds can be contaminated with such drug resistant bacteria which cause diseases in the domestic birds and human afterwards which are difficult to treat. Addition of antibiotics in the feeds for preventing diseases in the birds is another cause to raise resistance in the sensitive bacterial isolates.

In this study, Rifampin and Erythromycin are 90\% resistant against Klebsiella spp. whereas Ciprofloxacin and Ceftriaxone were the most sensitive. Pseudomonas spp. was $100 \%$ susceptible to Ceftriaxone. Staphylococcus aureus was completely resistant towards Kanamycin, Novobiocin and Erythromycin. Salmonella spp. and Shigella spp. both showed resistance towards Ceftriaxone. Novobiocin was susceptible for maximum isolates except Vibrio spp. which showed $100 \%$ resistance. And finally Aeromonas spp. was completely resistant towards Erythromycin. The resistant isolates which will cause disease in the domestic birds, could be transferred into the human body if consumed undercooked. Then the infection which might arise could not be treated using the antibiotics towards which they have become resistant. Choice of susceptible drugs is decreasing very fast. This may result in the death from simple diseases which will fail to resume for unavailability of appropriate susceptible drugs.

Homogenized poultry feed samples were subjected to detect antibacterial activity towards clinical bacterial isolates. The isolates included Pseudomonas spp., Staphylococcus spp., Vibrio spp., Escherichia spp. and Klebsiella spp. Antibacterial activity against these bacteria have been found to be negative.

Table 1: Number of different bacteria isolated from poultry feed.

\begin{tabular}{|c|c|c|c|c|c|c|c|c|c|c|}
\hline 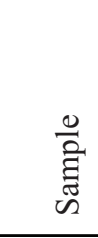 & $\sum_{i}^{0}$ & 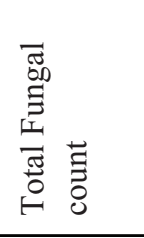 & $\begin{array}{l}\overline{0} \\
0 \\
\\
\end{array}$ & $\begin{array}{l}\frac{\dot{2}}{2} \\
\frac{\pi}{0} \\
\frac{0}{0} \\
\frac{0}{0} \\
\overrightarrow{0}\end{array}$ & 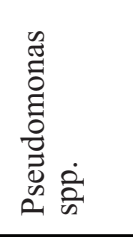 & 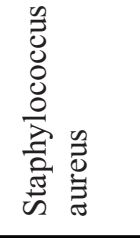 & 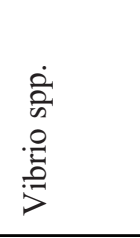 & 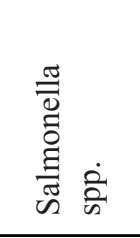 & 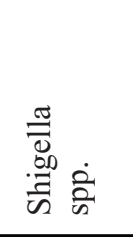 & 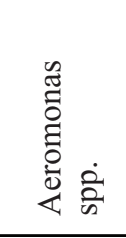 \\
\hline S1 & $5.0 \times 10^{6}$ & $2.0 \times 10^{4}$ & 0 & 0 & $2.0 \times 10^{4}$ & $1.0 \times 10^{4}$ & 0 & 0 & $5.0 \times 10^{4}$ & 0 \\
\hline S2 & $2.5 \times 10^{6}$ & $1.2 \times 10^{4}$ & 0 & 0 & 0 & $2.7 \times 10^{5}$ & $2.0 \times 10^{4}$ & 0 & $8.8 \times 10^{4}$ & 0 \\
\hline S3 & $5.0 \times 10^{4}$ & $1.3 \times 10^{4}$ & 0 & 0 & $1.6 \times 10^{4}$ & $1.8 \times 10^{5}$ & $2.1 \times 10^{5}$ & 0 & $1.1 \times 10^{6}$ & 0 \\
\hline S4 & $2.1 \times 10^{6}$ & $4.5 \times 10^{5}$ & 0 & $1.4 \times 10^{6}$ & $2.5 \times 10^{6}$ & $8.8 \times 10^{4}$ & $2.4 \times 10^{5}$ & $7.0 \times 10^{3}$ & $3.2 \times 10^{4}$ & 0 \\
\hline S5 & $4.0 \times 10^{5}$ & $2.0 \times 10^{3}$ & 0 & 0 & 0 & $5.0 \times 10^{3}$ & $1.8 \times 10^{5}$ & 0 & $2.3 \times 10^{5}$ & $2.9 \times 10^{5}$ \\
\hline
\end{tabular}


Table 2: Antibiotic susceptibility of the isolates

\begin{tabular}{|c|c|c|c|c|c|c|c|c|c|c|c|c|c|c|}
\hline \multirow{2}{*}{ 兽 } & \multicolumn{2}{|c|}{ 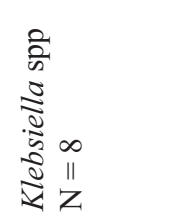 } & \multicolumn{2}{|c|}{ 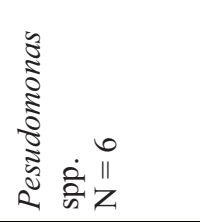 } & \multicolumn{2}{|c|}{ 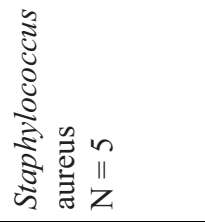 } & \multicolumn{2}{|l|}{ 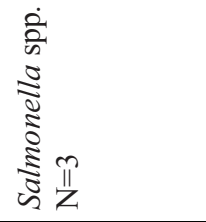 } & \multicolumn{2}{|c|}{ 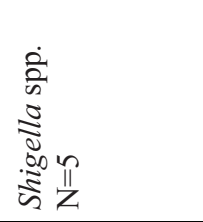 } & \multicolumn{2}{|l|}{ 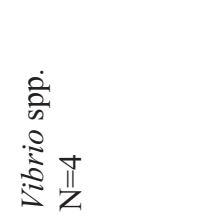 } & \multicolumn{2}{|l|}{ 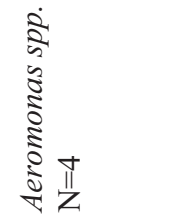 } \\
\hline & $\mathrm{R}$ & $\mathrm{S}$ & $\mathrm{R}$ & $\mathrm{S}$ & $\mathrm{R}$ & $\mathrm{S}$ & $\mathrm{R}$ & $S$ & $\mathrm{R}$ & $\mathrm{S}$ & $\mathrm{R}$ & $\mathrm{S}$ & $\mathrm{R}$ & $S$ \\
\hline $\begin{array}{l}\text { RFM } \\
(5 \mu \mathrm{g})\end{array}$ & $90 \%$ & $10 \%$ & $70 \%$ & $30 \%$ & $60 \%$ & $40 \%$ & $60 \%$ & $40 \%$ & $70 \%$ & $30 \%$ & $40 \%$ & $60 \%$ & $30 \%$ & $70 \%$ \\
\hline $\begin{array}{l}\text { CFT } \\
(30 \mu \mathrm{g})\end{array}$ & $10 \%$ & $90 \%$ & $0 \%$ & $100 \%$ & $10 \%$ & $90 \%$ & $0 \%$ & $100 \%$ & $0 \%$ & $100 \%$ & $20 \%$ & $80 \%$ & $10 \%$ & $90 \%$ \\
\hline $\begin{array}{l}\text { KAN } \\
(30 \mu \mathrm{g})\end{array}$ & $60 \%$ & $40 \%$ & $10 \%$ & $90 \%$ & $100 \%$ & $0 \%$ & $80 \%$ & $20 \%$ & $10 \%$ & $90 \%$ & $30 \%$ & $70 \%$ & $10 \%$ & $90 \%$ \\
\hline $\begin{array}{l}\text { NVB } \\
(30 \mu \mathrm{g})\end{array}$ & $40 \%$ & $60 \%$ & $30 \%$ & $70 \%$ & $80 \%$ & $20 \%$ & $100 \%$ & $0 \%$ & $40 \%$ & $60 \%$ & $80 \%$ & $20 \%$ & $40 \%$ & $60 \%$ \\
\hline $\begin{array}{l}\text { NA } \\
(30 \mu \mathrm{g})\end{array}$ & $30 \%$ & $70 \%$ & $80 \%$ & $20 \%$ & $100 \%$ & $0 \%$ & $60 \%$ & $40 \%$ & $10 \%$ & $90 \%$ & $100 \%$ & $0 \%$ & $10 \%$ & $90 \%$ \\
\hline $\begin{array}{l}\text { GEN } \\
(10 \mu \mathrm{g})\end{array}$ & $20 \%$ & $80 \%$ & $40 \%$ & $60 \%$ & $20 \%$ & $80 \%$ & $20 \%$ & $80 \%$ & $40 \%$ & $60 \%$ & $10 \%$ & $90 \%$ & $40 \%$ & $60 \%$ \\
\hline $\begin{array}{l}\text { AMO } \\
(30 \mu \mathrm{g})\end{array}$ & $20 \%$ & $80 \%$ & $20 \%$ & $80 \%$ & $0 \%$ & $100 \%$ & $40 \%$ & $60 \%$ & $30 \%$ & $70 \%$ & $45 \%$ & $55 \%$ & $30 \%$ & $70 \%$ \\
\hline $\begin{array}{l}\text { ER } \\
(15 \mu \mathrm{g})\end{array}$ & $90 \%$ & $10 \%$ & $70 \%$ & $30 \%$ & $100 \%$ & $0 \%$ & $50 \%$ & $50 \%$ & $75 \%$ & $25 \%$ & $20 \%$ & $80 \%$ & $100 \%$ & $0 \%$ \\
\hline $\begin{array}{l}\text { CIP } \\
(5 \mu \mathrm{g})\end{array}$ & $10 \%$ & $90 \%$ & $10 \%$ & $90 \%$ & $0 \%$ & $100 \%$ & $30 \%$ & $70 \%$ & $45 \%$ & $55 \%$ & $40 \%$ & $60 \%$ & $45 \%$ & $55 \%$ \\
\hline
\end{tabular}

N.B. $R=$ Resistant, $\mathrm{S}=$ Sensitive

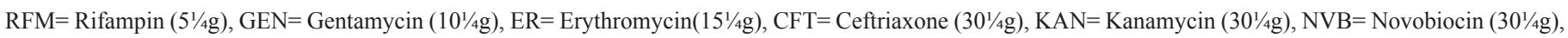
$\mathrm{NA}=$ Nalidixic Acid $\left(30^{1} / 4 \mathrm{~g}\right), \mathrm{AMO}=$ Amoxicillin $\left(30^{1} / 4 \mathrm{~g}\right), \mathrm{CIP}=$ Ciprofloxacin $\left(5 \frac{1}{4} \mathrm{~g}\right)$.

\section{Conclusion}

Poultry products are good sources of proteins. This sector is expanding in Bangladesh to meet the protein demand of the growing population. But this protein source can be responsible for public health hazards if it harbors adequate amount of pathogenic bacteria. Pathogenic bacteria can be introduced from the ingredients, storage conditions, environmental facilities. Commercially available good quality feeds should be provided to the domestic birds to avoid diseases of domestic birds as well as their transmission to consumers.

\section{Conflict of interest: None}

\section{References:}

1. Barakat R. 2004. Monitoring Feeds for Salmonella in Canada. Animal Feeds Workshop 2004, Atlanta, Georgia, USA.http://bsm.org.bd/images/ head.jpg

2. Rafloff EM. 2003. "Salmonella Reservoirs in Animals and Feeds", Journal of Poultry Science. 46(22): 7-9.

3. Smith WT. 2005. Feed chickens properly Co-operative extension. Extension service of Mississippi State University Service. pp 58-60.
4. Microlovestock. 1991. A little known small animals with a promising economic future. National Academic Press Washington, pp 79-160.

5. Obi CN and Ozugbo IJ. 2007. Microbiological analysis of poultry feeds sold in Umuahia main market, Abia State, Nigeria. Research Journal of Applied Sciences. 2(1): 22-25.

6. Ogbulie JN and Okpokwasili GC. 1998. Efficacy of chemotherapeutic agents in controlling bacterial diseases of cultured fish. Journal of Aquaculture in the Tropics. 13: $61-72$.

7. Gill C and Best R. 1998. Antibiotic resistance in U.S.A: Scientists to look more closely. Feed International. 19(8): 16 - 17.

8. Ruff MD. 1992. New Methods of Disease control. Feed Mix. 1: 15 - 18.

9. Hesseltine CW. 1984. Toxigenic Fungi - their toxins and health hazard. Koclarisha Press. Peoria, Illinois, 61604.

10. Betina, V. (Ed). 1989. Mycotoxins - Chemical, Biological and Environmetal Aspects. Amsterdam.12. Barnes M, Vallancourt J P and Gross W B. 2003. Diseases of poultry, 11 th Edition lowa State University Press, Amesia USA, pp 200-240.

11. Gilbert J. 1995. Analysis of Mycotoxins in Food and feed. Certification of DIN in wheat and Maize. American Pathology. 3(4): 263 - 268.

13. White DG and Torman J. 1995. Post harvest application of low rates of DMX - 7 mold inhibitor on storage fungi of corn during ambient air drying and storage. Applied Engineering in Agriculture. 11(4): $573-576$. 
14. Creppy EE. Review article. 2002. Update of survey, regulation and toxic effects of mycotoxins in Europe. Toxicol Lett. 127:19-28.

15. MAFF. 1993. Salmonella in Animal Feeding stuffs and Ingredients. January September 1993. Technical Report 3 of the Ministry of Agriculture fisheries and Foods. Animal Health (Zoonoses Division, London).

16. Morris MF, Pastorek JD, Yarg DE and Martin, DH. 1999. Epidemiology and outcomes associated with moderate to Heavy Escherichia Colonization. A.M. Intern Med. 149(78): 33-5.

17. Tabib Z, Jones FT, and Hamilton PB. 1981. Microbiological Quality of Poultry Feed and Ingredients. Poultry Science. 60:1392-1397.

18. Anderson KE and Richardson KE. 1999. Effects of Termin-8 and compound on the Microbiological and Physical Quality of Shell Eggs from Commercial Eggs laying chickens. Poultry Science. 70(1): 70.

19. Derouchey DP and Tyadal SP. 2004. Comparison of Methods for diagnosing Bacterial Fungi among poultry feeds. J.C. Clinical Micro. 27(13); 23-5.

20. Krstanovi V, Klapec T, Veli N and Milakovi Z. 2005. Contamination of malt barley and wheat by Fusarium graminearum and Fusarium culmorum from the crop years 2001-2003 in eastern Croatia. Microbiol Res. 160: 353-359.

21. D'Mello J, Placinta C and Macdonald A. 1999. Fusarium mycotoxins: a review of global implications for animal health, welfare and productivity. Anim Feed Sci Technol. 80:183-205.

22. Egal S, Hounsa A, Gong Y, Turner P, Wild C, Hall A, Hell K and Cardwell K. 2005. Dietary exposure to aflatoxin from maize and groundnut in young children from Benin and Togo, West Africa. Int J Food Microbiol. 104: 215-224.

23. Kan C and Meijer G. 2007. Th risk of contamination of food with toxic substances present in animal food. Anim Feed Sci Technol. 133: 84-108.

24. KrysiDska-Traczyk E, Perkowski J and Dutkiewicz J. 2007. Levels of fungi and mycotoxins in the samples of grain and grain dust collected from fie various cereal crops in eastern Poland. Ann Agric Environ Med. 14: $159-167$

25. Morgavi DP and Riley RT. 2007. A historical overview of fild disease outbreaks known or suspected to be caused by consumption of feed contaminated with Fusarium toxins. Anim Feed Sci Technol. 137: 201-212.

26. Anon. 2001. Salmonella: Coordinating Chemical and Thermal Control. Feed International December. pp 27-30.

27. Veldman A, Vahl HA and Borggreve GJ et al. 1995. A survey of the incidence of Salmonella species and enterobacteriaceae in poultry feed and feed components. Vet. Rec. 135:169-172.

28. Maciorowski KG, Jones FT, Plliai SD and Ricke SC. 2004. Incidence, Sources and Control of Food Borne Salmonella Spp. in Poultry Feed. Worlds Poultry Science Journal. 60: 446-457.

29. Okogun GRA, Jemikalajah DJ and Ebhohimen EV. 2016. Bacteriological evolution of poultry feeds in Ekpoma, Nigeria. African Journal of Cellular Pathology. 6: 6-9.

30. CheBkowski J. 2008. Mycotoxins and toxin-forming fungi, as a significant indicator of food and feed quality. Pol Poultry. 10: 22-27 (in Polish).

31. Hussein H and Brasel J. 2001. Toxicity, metabolism and impact of mycotoxins on humans and animals. Toxicology. 167: 101-134.

32. Onyeze Rosemary C, Onah Gloria T and Eluke Obinne C. 2013. Bacterial contaminants associated with commercial poultry feeds in Enugu, Nigeria. Int. J. LifeSc. Bt \& Pharm. Res. 2(3): 432-437.

33. American Public Health Association. 1998. Standard methods for the examination of water and waste water. American Public Health Association: Washington DC.

34. Cappuccino JG and Sherman N. 1996. Microbiology - A Laboratory Manual. The Benjamin/Cummings Publishing Co., Inc., Menlo Park, California.
35. Marjan S, Das KK, Munshi SK and Noor R. 2014. Drug-resistant bacterial pathogens in milk and some milk products. Nutrition \& Food Science. 44(3): 241-248.

36. Rahman F and Noor R. 2012. Prevalence of pathogenic bacteria in common salad vegetables of Dhaka Metropolis. Bangladesh Journal of Botany. 41(2), 159-162.

37. Sriram N and Reetha D. 2015. Isolation and characterization of dye degrading bacteria from textile dye effluents. Central European Journal of Experimental Biology. 4(2):5-10.

38. Singh RP, Singh PK, and Singh RL. 2014. Bacterial Decolorization of Textile Azo Dye Acid Orange by Staphylococcus hominis RMLRT03. Toxicol Int. 21(2): 160-166. doi: 10.4103/0971-6580.139797.

39. Noor R, Uddin MA, Haq MA, Munshi SK, Acharjee M and Rahman MM. 2013. Microbiological study of vendor and packed fruit juices locally available in Dhaka city, Bangladesh. Int Food Res J. 20(2):1011-1015.

40. Yasmin S, Parveen S, Munna MS and Noor R. 2015. Detection of Salmonella spp. and Microbiological Analysis of Milk and Milk Based Products Available within Dhaka Metropolis, Bangladesh. British Microbiology Research Journal. 5(6): 474-480.

41. Ahmed T, Baidya S, Sharma BC, Malek M, Das KK, Acharjee M, Munshi SK and Noor R. 2003. Identification of drug-resistant bacteria among export quality shrimp samples in Bangladesh. Asian J Microbiol Biotech Env Sci. 15(4): 31-36.

42. Sultana S, Tarafder GH, Siddiqui TA, Shaha BC, Walliullah M, Ahmed T, Munna MS, Noor AF, Popy SK, Das KK, Acharjee M, Urmi NJ, Rahman T and Noor R. 2014. Microbiological quality analysis of shrimps collected from local market around Dhaka city. Int Food Res J. 21(1): 33-38.

43. Fatema N, Acharjee M and Noor R. 2013. Microbiological profiling of imported apples and demonstration of bacterial survival capacity through in vitro challenge test. Am J Microbiol Res. 1(4): 98- 04.

44. Uddin MA, Haque HMM and Noor R, 2011. Isolation and Identification of Pathogenic Escherichia coli, Klebsiella spp. And Staphylococcus spp. in Raw Milk Samples Collected from Different Areas of Dhaka City, Bangladesh. Stamford J Microbiol. 1(1): 19-23.

45. Hald T, Wingstrand A, Bronsted T and Wong DM. 2006. Human Health Impact of Salmonella Contamination in Imported Soybean Products: a Semi Quantitative Risk Assessment. Food Borne Pathogens and Diseases. 34: $422-431$.

46. Crump JA, Griffen PM and Angulo FJ. 2002. Bacterial Contamination of Animal Feed and its Relationship to Food Borne Illness. Infect. Dis. 35: 859-865.

47. Jawetz E, Melnick J L and Adelberg E . 1995. Medical Microbiology. Appleton and Lange, Norwalk, pp 656.

48. Centers for Disease Control and Prevention (CDC). Tracking and Reporting Foodborne Disease Outbreaks; 2015. Available at: http://www.cdc.gov/ features/dsfoodborneoutbreaks/ [Accessed October 31, 2015].

49. European Food Safety Authority (EFSA) and European Centre for Disease Prevention and Control (ECDC). 2015. The European Union Summary Report on Trends and Sources of Zoonoses, Zoonotic Agents and Foodborne Outbreaks in 2013. EFSA Journal. 13(1): 3991, pp 162, DOI: 10.2903/j.efsa.2015.3991.

50. Kidd RS, Rossignol AM and Grmroth MJ. 2002. Salmonella and other Enterobacteriaceae in animal feed ingredients and antimicrobial resistance in western Oregon. J. Environ. Health. 64: 9-16.

51. Boyer CL, Burner DW and Brown JA. 1985. Salmonella organisms isolated from poultry feed. Avian Dis. 2: 396-401.

52. Commission Regulation (EU) 142/2011, annex XIII, chapter 2.

53. Dutta S, Hassan MR, Rahman F, Jilani MFA and Noor R. 2013. Study of antimicrobial susceptibility of clinically significant microorganims isolated from selected areas of Dhaka, Bangladesh. Bang J Med Sci. 12(1): 34-42.

54. Duin DV and Paterson D. 2016. Multidrug Resistant Bacteria in the Community: Trends and Lessons Learned. Infect Dis Clin North Am. 30(2): 377-390. 